The Relation between Firm Growth and Stock Returns of ...

Ghada Saeed Abdelsalam Souliman

\title{
The Relation between Firm Growth and Stock Returns of Nonfinancial Firms in Egyptian Stock Exchange
}

\section{Ghada Saeed Abdelsalam Souliman}

\begin{abstract}
$\underline{\text { Abstract }}$
The main purpose of the research is to investigate whether there is a relation between firm growth and stock returns in Egyptian Stock Exchange. Sample size of the study is 77 firms of nonfinancial firms listed on Egyptian Stock Exchange. The required data were collected from firms' financial statements from 2010-2014. Firm growth is calculated by two measures which are: Total asset growth, and sales weighted fixed asset growth. Stock return is calculated using the appreciation in stock price divided by the original price for each period. Panel model estimation was used in the analysis. Results of the analysis revealed that there is no association between total asset growth and stock returns, there is positive association between sales weighted fixed asset growth and stock returns.
\end{abstract}




\section{جامهة قناة السويس - كلية التجارة إلسهماعلية}

The Relation between Firm Growth and Stock Returns of ...

Ghada Saeed Abdelsalam Souliman

تهدف الدر اسة إلى اختبار العلاقة بين نمو الثركة، وعائدات الاسهم و

\section{الملخص}

ذللك بالتطبيق على الثركات غير المالية المقيدة في البورصة المصنية ندرية. تتمثل

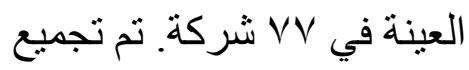

البيانات اللازمة للدر اسة من خلال القوائم المالية للثركات من الفترة

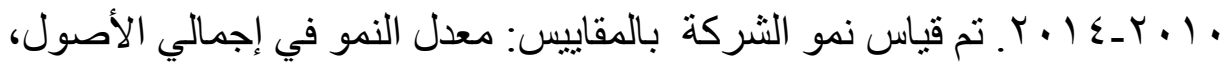

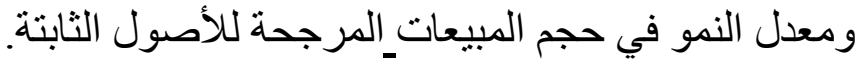

تم قياس عائدات الأسهم بالتغير في السعر مقسوما على السعر في بداية

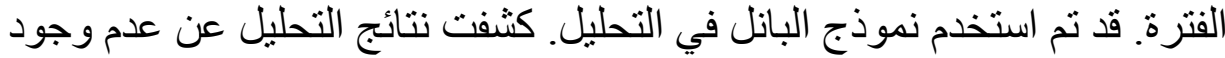

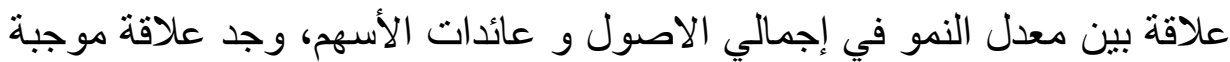

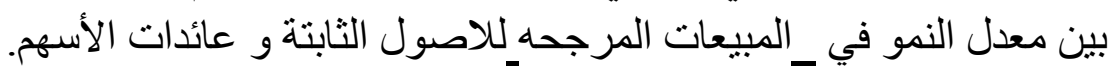


The Relation between Firm Growth and Stock Returns of ...

\section{1- INTRODUCTION}

Firm growth and decline is the core of finance and economic dynamics. Individual businesses are interested in determining the firm growth because it measures the firm ability to increase sales and expand its operations. Firm growth study is heterogeneous in nature, and the differences are growth indicator, firm growth measures, and differences in processes by which firm growth occurs.

Stock market is an important way for firms to raise their fund. It allows firms to be publicly traded and raise fund to expand and spend for their activities. So, the fund the firm gets through issuing stocks can be used in growing the firm. But in return investors deserve return. This research examines whether growing the firm affects stock return or not and if found, what is the nature of the relation.

The research examines the relation between firm growth and cross section of stock returns. Research population is composed of all nonfinancial firms listed at Egyptian Securities Exchange. Secondary data are extracted from the financial statements of the firms over the period of 2010-2014. Firm growth is measured by the measures: total asset growth rate, and sales weighted fixed assets growth rate. Stock return is measured by change in price plus dividend divided by the price at the beginning of the period.

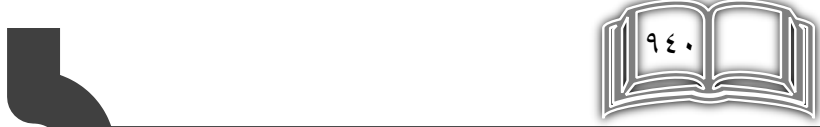


The Relation between Firm Growth and Stock Returns of ...

Ghada Saeed Abdelsalam Souliman

\section{Measures of Firm Growth and Stock Returns: Review of The Relevant Literature}

\subsection{Firm growth}

\subsubsection{Total assets growth and return}

Chen et al., (2008) provided empirical evidence on the impact of firm asset growth on stock returns using data on nine equity markets in the Pacific-Basin region (PACAP). They found that there is a significant negative relation between firms' asset growth and stock returns subsequently.

They have examined if the weak effect of asset growth in the region is a result of lower sensitivity of subsequent stock return to asset growth or less dispersion of firm growth. They found that the firms in PACAP region are similar in terms of asset growth. They also showed that the sensitivity of future stock return to asset growth is lower in the PACAP region. So, the degree of growth similarity and sensitivity of stock return to asset growth support explaining the variation of the effect across the nine markets within the region.

Cooper et al., (2008) have examined the firm asset investment level effects on return by examining the relation between firm asset growth and subsequent cross-sectional stock returns. The research showed the ability of asset growth

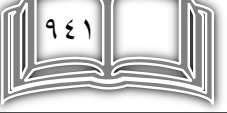


The Relation between Firm Growth and Stock Returns of ...

Ghada Saeed Abdelsalam Souliman

to anticipate the cross-section of returns due to its capability to capture common return effects across the firm's total investment components or financing activities. The research use total assets growth effects of all firm investment and disinvestment as a measure of firm growth. They have explored that firm asset growth rate is stronger in determining future returns than other growth measures.

They have used a simple and comprehensive firm growth measure, the annual percentage change in total assets. They have documented there is a strong negative relation between firm's asset growth and subsequent returns.

Cooper et al., (2009) explained the impact of asset growth on stock returns, and concluded that asset growth rate has large explanatory power as determinant of cross-section stock return. They divided the firms according to percentage change in total assets into ten portfolios. They were holding portfolios for one year. They concluded that mean annual portfolio return of stocks with highest past assets growth is lower than mean annual portfolio returns of stocks with lowest past assets growth by $22 \%$.

They have tested the ability of asset growth to interpret the cross-section of returns in regression format, and they found that there is a strong and significant negative relation 
The Relation between Firm Growth and Stock Returns of ...

Ghada Saeed Abdelsalam Souliman

between subsequent returns and historical asset growth of the firm.

They found that high asset growth firms with high past returns tend to have lower subsequent returns, and low asset growth firms with low past returns tend to have higher subsequent stock returns.

Lipson et al., (2009) provided evidence that the asset growth impact is closely linked to the existence of arbitrage cost suggesting that mispricing is an important determinant of the return pattern.

They used idiosyncratic volatility as arbitrage costs measure essential to sustain mispricing to be a condition for asset growth effects in the cross-section of returns and time series patterns in factor loadings. They explored that the relation between asset growth and subsequent stock returns is negative in light of two possible explanations: compensation of risk and costly arbitrage. If mispricing occurs within arbitrage bounds, it does not need violate market efficiency.

Yao et al., (2011) have explored the asset growth effect on stock returns using data on nine equity markets in Asia, which are Japan, Malaysia, China, Malaysia, Hong Kong, Korea, Taiwan, Singapore, Malaysia, and Indonesia. They

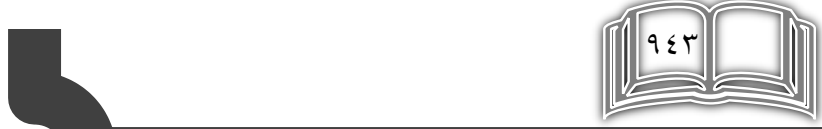


The Relation between Firm Growth and Stock Returns of ...

Ghada Saeed Abdelsalam Souliman

focused in the study on the Asian financial markets because many Asian firms primarily depend on bank-based financial system in contrast to U.S. markets. They concluded that there is a wide negative relation between asset growth and stock returns in the Asian markets during the period from 1981 to 2007.

Gray et al., (2011) examined the relation between total asset growth and the cross-sectional stock returns in Australian stock market. They examined if the asset growth effect is due to risk or mispricing.

Their main finding is that there is a negative relation between growth in total asset and subsequent stock returns. An equally-weighted portfolio of low growth big stocks has higher stock return than high growth big stocks portfolio. Also, at individual stock level of analysis, there is a negative impact of asset growth for big stocks.

They found that the asset growth impact is a result of mispricing. But according to risk-based explanation, the big spread portfolio abnormal returns are statistically insignificant.

Lie et al., (2012) examined the predictive power of asset growth for stock return using the international equity

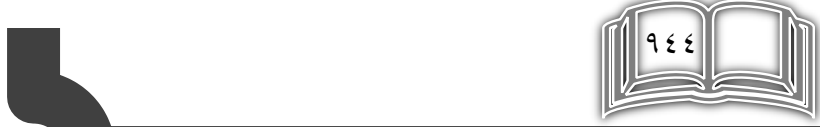


The Relation between Firm Growth and Stock Returns of ...

Ghada Saeed Abdelsalam Souliman

markets. They found that total asset growth rate has the best predictive power for stock returns. It is strong for most industries, regions, countries, and different sample periods, and for small and large- cap firms. They also found that the asset growth impact is significant up to the fourth year after measuring the total asset growth.

They concluded that there is a negative effect of growth in asset/investment on subsequent stock returns, with twoyears total asset growth rates offering the greatest predictive power by examining data sampled from the international equity markets.

Wen (2013) examined whether firm asset growth affects the aggregate stock market. He constructed an aggregate measure of asset growth; examines its time-series implications for the stock market returns, and its relation to the cross sectional stock returns.

He has used the measure of firm growth in Cooper et al., (2008), which is total assets growth. He found that asset growth is better predictor of cross-sectional returns. From investment decomposition, growth in cash and other assets are significantly and negatively related with future stock market returns. From financing decomposition, growth in operating

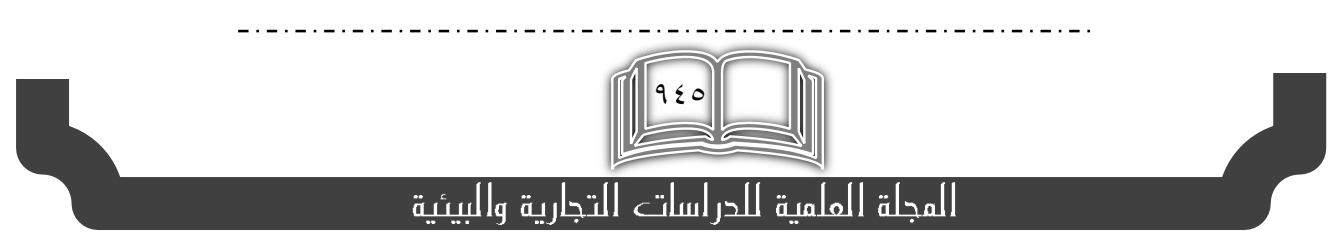


The Relation between Firm Growth and Stock Returns of ...

Ghada Saeed Abdelsalam Souliman

liability, equity financing, and retained earnings are stronger related with future stock market returns.

Watanabe et al., (2013) tested the relation between asset growth and stock returns in 53 countries in Africa, Asia, Australia, Europe, and America.

They found that higher asset growth rate leads to lower stock returns in the different equity markets. They also found that there are large variations in the impact of asset growth. The negative relation is stronger in the developed markets and markets with efficient priced stocks.

They also concluded that the country characteristics such as limits to arbitrage, investor protection, and accounting quality do not affect the relation of asset growth and stock returns.

Suresh et al., (2014) examined the impact of asset growth on stock returns in Pakistan Stock Market. They use group of independent variables. They tested whether the association of asset mechanisms can be related to firm stock returns. They concluded that there is a meaningful relation between the rate of stock return and the total asset.

Wang et al., (2015) examined the relation between asset growth and cross-section of Chinese stock return. Data 
The Relation between Firm Growth and Stock Returns of ...

Ghada Saeed Abdelsalam Souliman

used to discuss if there is investment effect, which factors lead to it; risk factors or behavioral factors using two approaches (portfolio analysis, and cross-section analysis).

They showed that investment affect significantly the Chinese stock market. They found that the firm with higher investment has lower cross-section stock returns. They found that the behavioral finance theory is better in explaining the investment effect on stock return than risk-based theory.

\subsubsection{Sales-weighted fixed assets growth}

According to Eldomiaty (2010), there are many factors affect firm growth that leads to appearing two theories to explain these factors which are growth-learning theory and growth-size theory. Growth-size theory focuses on the relation between firm growth and its size. Growth-learning theory focuses on the behavior of cost function as a result of firm learning.

Eldomiaty has explained that both growth-size and growth learning theories may complete each other. For example, when the firm needs to increase its sales, it will lead to increasing cost.

The approach of the research is to use sales ratios in examining growth size relation, and use cost ratios to examine 
The Relation between Firm Growth and Stock Returns of ...

Ghada Saeed Abdelsalam Souliman

growth learning relation. Then it uses both ratios together to find its relation with firm growth. It examined contribution of ratios to low and high-growth firms.

It also concluded that the explanatory power of sales and cost models are relatively low, which means that firm growth depend on other factors. He introduced a measure of firm growth relies on sales-weighted fixed assets growth. It is characterized by taking into account sales and fixed assets growth at the same time and it related fixed assets growth to firm's maximum sales.

\subsection{Measures of firm growth}

(a) Total asset growth rate

Chen et al., (2008) define annual firm total asset growth rate as "year-over-year percentage change in total assets". Cooper et al., (2008),Chen et al., (2008), Titman et al., (2010) and Wang el al., (2015) use the equation

$$
A G_{t}=\frac{\text { Total assetst }_{t-1}-{\text { Total } \text { assets }_{t-2}}_{\text {Total }_{\text {assets }}}}{\text { Tot }}
$$


The Relation between Firm Growth and Stock Returns of ...

Ghada Saeed Abdelsalam Souliman

This research calculates total assets growth by:-

Total assets growth

$$
=\frac{\text { Total assetst }_{t}-\text { Total assets }_{t-1}}{\text { Total assets }_{t-1}} \times 100
$$

(b) Sales-weighted fixed assets growth

Eldomiaty (2010) has introduced a firm growth measure relies on sales-weighted fixed assets growth which is:-

$$
\text { Firm growth }=\operatorname{Ln}\left(\frac{\mathrm{FA}_{t}}{\mathrm{FA}_{t-1}}\right) \frac{\text { sales }_{t}}{\text { max. sales }}
$$

He used this measure because it takes into account sales growth and fixed assets at the same time and relates fixed assets growth to maximum sales the firm can achieve.

\subsection{Measure of stock returns}

As shown before, there are two types of firm stock, common stocks and preferred stocks. Both types give holders rate of return (Saunders\& Cornett, pp.246). Stock return can be measured by formula which is an appreciation in the price plus any dividend paid divided by the original stock price. The income sources from a stock are dividends and its increase in value. It as measured as below:- 
The Relation between Firm Growth and Stock Returns of ...

$$
\text { stock return }(r)=\frac{\left(p_{1}-p_{0}\right)+D}{P_{0}}
$$

$\mathrm{P}_{0}=$ Initial stock price, $\mathrm{P}_{1}=$ Ending stock price (period 1$)$,

$\mathrm{D}=$ Dividends

We concluded from previous literature the following research hypothesis:

$\mathbf{H}_{1}$ : A positive association exists between total assets growth rate and stock returns.

$\mathbf{H}_{2}$ : A positive association exists between Sales-weighted fixed assets growth rate and stock returns.

\section{3- RESEARCH METHODOLOGY}

\subsection{Research Design}

This research is designed to study the association between firm growth and stock returns using existing literature review and analyzing some items in the financial statements of nonfinancial firms listed at Egyptian Securities Exchange. The standard statistical tests are utilized in order to test the hypotheses. These tests are as follows:- 
The Relation between Firm Growth and Stock Returns of ...

Ghada Saeed Abdelsalam Souliman

\subsection{Unit of analysis}

Units of analysis used in the study are nonfinancial firms listed at Egyptian Securities Exchange.

\subsection{Time Horizon}

The data frequency is annual. The type of data is crosssectional that covers the period from 2010-2014.

\subsection{Data Collection Method}

Secondary data are obtained from financial statements of firms listed at Egyptian securities exchange.

\subsection{Data Source}

Data is collected from financial statements of nonfinancial firms listed at Egyptian Securities Exchange from Egypt for Information dissemination (EGID) which is the sole aggregator and authorized distributor of the Egyptian Exchange's listed companies' information.

\subsection{Population}

The population of the study is the nonfinancial firms listed at Egyptian securities exchange. The nonfinancial firms are classified into 17 sectors with 178 firms.

\subsection{Sample}

Population of the study which are nonfinancial firms listed at Egyptian Securities Exchange is divided into sectors (strata) based on the nature of the business, so stratified random sampling is the most suitable approach for the study.

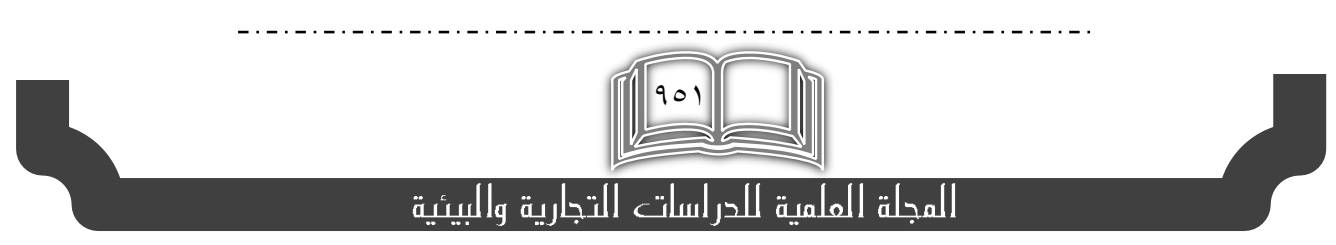


The Relation between Firm Growth and Stock Returns of ...

Ghada Saeed Abdelsalam Souliman

According to Sekaran 2003, when the population is 178 firm which approximately 180, the appropriate sample size is 122 firm.

The sample size is proportionally distributed according to number of firms in each sector.

The final sample is comprised of 77 nonfinancial listed firms in the Egyptian Exchange during a five year sample period (2010-2014). Firms with non-December 31 fiscal year-end are excluded to facilitate interpretation of results in the context of the economics of the period. Firms with insufficient data to calculate any of the independent variables are excluded. Finally, sample excludes firms trading in foreign currency to unify the currency.

\section{4- STATISTICAL ANALYSIS}

First: Test of Normality for dependent and independent variables.

Table (1):

Descriptive statistics for dependent and independent variables from 2010 to 2014.

\begin{tabular}{|c|c|c|c|}
\hline & $\begin{array}{c}\text { Stock returns } \\
(\mathrm{R})\end{array}$ & $\begin{array}{c}\text { Total Asset } \\
\text { Growth } \\
\text { (TAG) }\end{array}$ & $\begin{array}{c}\text { Sales Weighted } \\
\text { Fixed Assets } \\
\text { Growth (SWFAG) }\end{array}$ \\
\hline Mean & -0.056239 & 0.030199 & -0.004759 \\
\hline Median & -0.064726 & 0.031391 & -0.001000 \\
\hline
\end{tabular}


The Relation between Firm Growth and Stock Returns of ...

Ghada Saeed Abdelsalam Souliman

\begin{tabular}{|c|c|c|c|}
\hline Maximum & 0.312982 & 0.142555 & 0.069441 \\
\hline Minimum & -0.435470 & -0.095001 & -0.076748 \\
\hline Std. Dev. & 0.130574 & 0.045269 & 0.030342 \\
\hline Skewness & 0.050550 & 0.016108 & -0.342234 \\
\hline Kurtosis & 3.289889 & 2.650703 & 2.611610 \\
\hline & & & \\
\hline Jarque-Bera & 1.512038 & 1.973871 & 9.935302 \\
\hline Probability & 0.469532 & 0.372717 & $0.006959^{* *}$ \\
\hline & & & \\
\hline Observations & 385 & 385 & 385 \\
\hline
\end{tabular}

**Parameter is significant at the (.01) level.

Second: panel model estimation for each independent variable on stock return

\section{Panel model estimation for total asset growth on stock returns}

$\mathrm{H}_{1}$ : A positive association exists between total asset growth and stock returns.

Table (2):

panel model estimation for TAG on R.

\begin{tabular}{|c|c|c|c|c|c|c|c|}
\hline \multirow{2}{*}{$\begin{array}{l}\mathbf{N} \\
\mathbf{o}\end{array}$} & \multirow{2}{*}{$\begin{array}{c}\text { Independent } \\
\text { Variables }\end{array}$} & \multirow{2}{*}{$\begin{array}{l}\text { Estimated } \\
\text { coefficient }\end{array}$} & \multicolumn{2}{|c|}{$t$ test } & \multicolumn{2}{|c|}{$F$ test } & \multirow{2}{*}{$\begin{array}{l}\mathbf{R}^{2} \\
\%\end{array}$} \\
\hline & & & value & Sig. & value & Sig. & \\
\hline 1 & $\begin{array}{c}\text { Total asset } \\
\text { growth }\end{array}$ & -0.043542 & -0.225523 & 0.8217 & \multirow{2}{*}{7.573554} & \multirow{2}{*}{$0.000000^{* * * *}$} & \multirow{2}{*}{66.9379} \\
\hline 2 & Constant & -0.054924 & -7.576554 & $0.0000 * * *$ & & & \\
\hline & & & & & & & \\
\hline
\end{tabular}


The Relation between Firm Growth and Stock Returns of ...

Ghada Saeed Abdelsalam Souliman

\begin{tabular}{|c|c|c|}
\hline $\begin{array}{c}\text { Akaike info } \\
\text { criterion }\end{array}$ & Schwarz criterion & Hannan-quinn criterion \\
\hline-1.917169 & -1.075179 & -1.583233 \\
\hline
\end{tabular}

According to panel estimation model of TAG on $R$ model using least squares ad autoregressive errors (AR) in table (2), it can be concluded that:

\section{1- Coefficient of determination:}

total asset growth explains (66.9379\% ) from total variation of dependent variable ( firm's stock returns), and the rest percent due to either the random error in the regression model or other Independent Variables excluded from regression model.

\section{2- F test:}

$F$ test is a test to determine if there is a linear relationship between the dependent variable $(\mathrm{R})$ and total asset growth as independent variable. Since the value of "F test" is (7.573554) with significant at the (0.01) level, so total asset growth as independent variable can accepted in the model and the result can be applied.

\section{3- T test:}

The significant level of t-test is greater than (0.05), so there is no association between total asset growth and stock returns. 
The Relation between Firm Growth and Stock Returns of ...

Ghada Saeed Abdelsalam Souliman

\section{4- The Jarque-Bera Test:}

Since the significance value of the test statistic $(\geq 0.05)$, then we would not reject the null hypothesis $\left(\mathrm{H}_{0}\right)$ : Errors are normally distributed, and we conclude that the observed distribution corresponds to or equal the theoretical distribution, i.e. the observed errors are normally distributed.

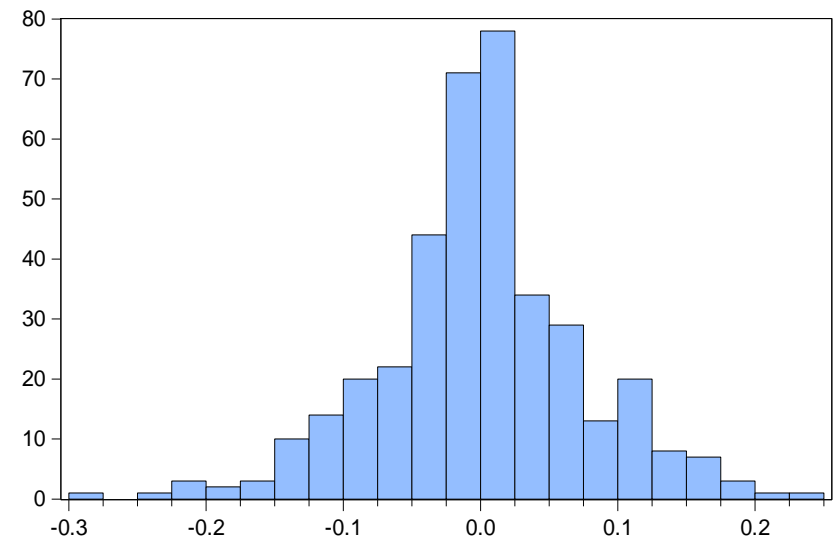

Series: Standardized Residuals Sample 20102014

Observations 385

Mean

Median

Maximum

Minimum

Std. Dev.

Skewness

Kurtosis

Jarque-Bera

Probability 9.37e-19

0.001117

0.239471

$-0.284238$

0.075079

$-0.118391$

3.959769

15.67626

0.000394

Figure (1): The Jarque-Bera test of normality for residuals.

\section{5- Regression model:}


The Relation between Firm Growth and Stock Returns of ...

Ghada Saeed Abdelsalam Souliman

Stock Return $(\mathrm{R})=\mathbf{- 0 . 0 4 3 5 4 2}$ Total asset growth $-\mathbf{0 . 0 5 4 9 2 4}$

\section{6- Redundant fixed effect test}

Table (3):

Redundant Fixed Effects Tests.

Test cross-section and period fixed effects

\begin{tabular}{cccc}
\hline \hline Effects Test & Statistic & d.f. & Prob. \\
\hline \hline Cross-section F & 7.990891 & $(76,303)$ & 0.0000 \\
Cross-section Chi-square & 423.519217 & 76 & 0.0000 \\
Period F & 0.451897 & $(4,303)$ & 0.7710 \\
Period Chi-square & 2.289945 & 4 & 0.6826 \\
Cross-Section/Period F & 7.615513 & $(80,303)$ & 0.0000 \\
Cross-Section/Period Chi- & 424.336009 & 80 & 0.0000 \\
square & & & \\
\hline \hline
\end{tabular}

The results reported in table (3) show that:

The first set consists of two tests ("Cross-section F" and "Cross-section Chi-square") that evaluate the joint significance of the cross-section effects. The two statistic values are $(7.99,423.52)$. The associated $\mathrm{p}$-values strongly 
The Relation between Firm Growth and Stock Returns of ...

Ghada Saeed Abdelsalam Souliman

reject the null that the cross-section effects are redundant, and there is cross-section fixed effect.

The next two tests evaluate the significance of the period dummies. The two statistic values $(0.452,2.29)$ and the associated p-values are greater than 0.05 , so the forms of the statistic accept the null hypothesis of no period effects.

The last two tests evaluate the joint significance of both effects. Both of the test statistics reject the null in which the cross-section and period are redundant. There is cross-section and period fixed effect.

\section{7- Cross-section fixed effects test equation:}

$$
\text { Table (4): }
$$

cross-section fixed effect.

Cross-section fixed effects test equation:

\begin{tabular}{ccccc}
\hline \hline Variable & \multicolumn{2}{c}{ Coefficient Std. Error t-Statistic } & Prob. \\
\hline \hline TAG & 0.198072 & 0.147715 & 1.340905 & 0.1808 \\
C & -0.062220 & 0.008029 & -7.749328 & 0.0000 \\
\hline \hline \multicolumn{5}{c}{ Effects Specification } \\
\hline \hline
\end{tabular}

Period fixed (dummy variables)

R-squared $\quad 0.006711$ Mean dependent var -0.056239 
The Relation between Firm Growth and Stock Returns of ...

Ghada Saeed Abdelsalam Souliman

Adjusted R-squared $\quad-0.006393 \quad$ S.D. dependent var 0.130574

S.E. of regression 0.130990 Akaike info criterion -1.211924

Sum squared resid 6.503062 Schwarz criterion -1.150315

Log likelihood 239.2954 Hannan-Quinn criter. -1.187490

F-statistic $\quad 0.512115$ Durbin-Watson stat 0.200388

Prob(F-statistic) $\quad 0.767123$

The panel model is as follows: $\quad \mathrm{R}=0.198072 \mathrm{TAG}-0.062220$

Table (4) concludes that since the significant level of total asset growth is greater than (0.05), so it is not accepted in the cross-section fixed effects test equation.

\section{8- Period fixed effects test equation:}

Table(5):

Period fixed effects test equation

\begin{tabular}{ccccc}
\hline \hline Variable & Coefficient & Std. Error & t-Statistic & Prob. \\
\hline \hline TAG & -0.052733 & 0.192098 & -0.274509 & 0.7839 \\
C & -0.054646 & 0.007216 & -7.572489 & 0.0000 \\
\hline \hline
\end{tabular}

Effects Specification

Cross-section fixed (dummy variables)

$\begin{array}{cccc}\text { R-squared } & 0.667407 & \text { Mean dependent var } & -0.056239 \\ \text { Adjusted R- } & 0.583988 & \text { S.D. dependent var } & 0.130574\end{array}$


The Relation between Firm Growth and Stock Returns of ...

Ghada Saeed Abdelsalam Souliman

squared

\begin{tabular}{cccc}
$\begin{array}{c}\text { S.E. of regression } \\
\text { Sum squared }\end{array}$ & 0.084219 & Akaike info criterion & -1.932000 \\
resid & 2.177486 & Schwarz criterion & -1.131083 \\
Log likelihood & 449.9101 & Hannan-Quinn criter. & -1.614353 \\
F-statistic & 8.000647 & Durbin-Watson stat & 0.601203 \\
Prob(F-statistic) & 0.000000 & & \\
\hline
\end{tabular}

The panel model is as follows: $\mathrm{R}=-0.052733 \mathrm{TAG}-0.054646$

Table (5) concludes that since the significant level of total asset growth is greater than (0.05), so it is not accepted in the period fixed effects test equation.

\section{9- Cross-section and period fixed effects test equation:}

Table (6):

Cross-section and period fixed effects test.

\begin{tabular}{|c|c|c|c|}
\hline Variable & Coefficient & Std. Error t-Statistic & Prob. \\
\hline $\mathrm{TAG}$ & 0.195655 & $0.147046 \quad 1.330575$ & 0.1841 \\
\hline $\mathrm{C}$ & -0.062147 & $0.007995-7.773581$ & 0.0000 \\
\hline R-squared & 0.004601 & Mean dependent var & -0.056239 \\
\hline $\begin{array}{c}\text { Adjusted R- } \\
\text { squared }\end{array}$ & 0.002002 & S.D. dependent var & 0.130574 \\
\hline $\begin{array}{l}\text { S.E. of } \\
\text { regression }\end{array}$ & 0.130443 & Akaike info criterion & -1.230582 \\
\hline Sum squared & 6.516873 & Schwarz criterion & -1.210046 \\
\hline
\end{tabular}


The Relation between Firm Growth and Stock Returns of ...

Ghada Saeed Abdelsalam Souliman

resid

$\begin{array}{cccc}\text { Log likelihood } & 238.8870 & \begin{array}{c}\text { Hannan-Quinn } \\ \text { criter. }\end{array} & -1.222437 \\ \text { F-statistic } & 1.770430 & \text { Durbin-Watson stat } & 0.203357 \\ \text { Prob(F-statistic) } & 0.184120 & & \end{array}$

The panel model is as follows: $\mathrm{R}=0.195655 \mathrm{TAG}-0.062147$

Table (6) concludes that since the significant level of total asset growth is greater than (0.05), so it is not accepted in the cross-section and period fixed effects test equation.

\title{
10- Residual Cross-Section Dependence Test
}

\author{
Table (7):
}

Residual Cross-Section Dependence Test.

Null hypothesis: No cross-section dependence (correlation) in residuals

\begin{tabular}{cccc}
\hline \hline Test & Statistic & d.f. & Prob. \\
\hline \hline Breusch-Pagan LM & 10067.12 & 2926 & 0.0000 \\
Pesaran scaled LM & 92.34336 & & 0.0000 \\
Bias-corrected scaled LM & 82.71836 & & 0.0000 \\
Pesaran CD & -0.411319 & & 0.6808
\end{tabular}


The Relation between Firm Growth and Stock Returns of ...

Ghada Saeed Abdelsalam Souliman

Since the significant of Breusch-Pagan LM, Pesaran scaled LM, and Bias-corrected scaled LM are less than 0.001, then we reject the null hypothesis (H0): there is no crosssection dependence (correlation in residuals), But the significant of the last test (Pesaran CD) is greater than 0.05, so we accept the null: No cross-section dependence (correlation) in residuals.

\section{Panel model estimation for sales weighted fixed asset growth on stock returns:}

$\mathrm{H}_{2}$ : A positive association exists between sales weighted fixed asset growth and stock returns.

Table (7):

panel model estimation for SWFAG on R.

\begin{tabular}{|c|c|c|c|c|c|c|c|}
\hline \multirow{2}{*}{ No } & \multirow{2}{*}{$\begin{array}{l}\text { Independent } \\
\text { Variables }\end{array}$} & \multirow{2}{*}{$\begin{array}{l}\text { Estimated } \\
\text { coefficient }\end{array}$} & \multicolumn{2}{|c|}{$t$ test } & \multicolumn{2}{|c|}{ F test } & \multirow{2}{*}{$\begin{array}{l}\mathbf{R}^{2} \\
\%\end{array}$} \\
\hline & & & value & Sig. & value & Sig. & \\
\hline 1 & $\begin{array}{l}\text { Sales weighted } \\
\text { fixed asset growth }\end{array}$ & 0.529814 & 2.1231758 & $0.02 * *$ & \multirow[t]{2}{*}{7.696940} & \multirow[t]{2}{*}{$0.001 * * *$} & \multirow[t]{2}{*}{67.29} \\
\hline 2 & Constant & -0.053717 & -11.93734 & $0.0000^{* * *}$ & & & \\
\hline \multicolumn{2}{|c|}{ Akaike info criterion } & \multicolumn{3}{|c|}{ Schwarz criterion } & \multicolumn{3}{|c|}{ Hannan-quinn criterion } \\
\hline & -1.928015 & \multicolumn{3}{|c|}{-1.086026} & \multicolumn{3}{|c|}{-1.594079} \\
\hline
\end{tabular}


The Relation between Firm Growth and Stock Returns of ...

Ghada Saeed Abdelsalam Souliman

According to panel estimation for SWFAG on R model using least squares ad autoregressive errors (AR) in table (7), it can be concluded that:

\section{1- Coefficient of determination:}

Sales weighted fixed asset growth explains (67.29\%) from total variation of dependent variable ( firm's stock returns), and the rest percent due to either the random error in the regression model or other Independent Variables excluded from regression model.

\section{2- F test:}

$F$ test is a test to determine if there is a linear relationship between the dependent variable (R) and sales weighted fixed asset growth as independent variable. Since the value of "F test" is (7.696940) with significant at the (.001) level, so sales weighted fixed asset growth as independent variable can accepted in the model and the result can be applied.

\section{3- T test:}

The significant level of t-test is less than (0.05), so there is an association between sales weighted fixed asset growth and stock returns. 
The Relation between Firm Growth and Stock Returns of ...

Ghada Saeed Abdelsalam Souliman

\section{4- The Jarque-Bera Test:}

Since the significance value of the test statistic $(\geq 0.05)$, then we accept the null hypothesis $\left(\mathrm{H}_{0}\right)$ : Errors are normally distributed, and we conclude that the observed distribution corresponds to or equal the theoretical distribution, i.e. the observed errors are normally distributed.

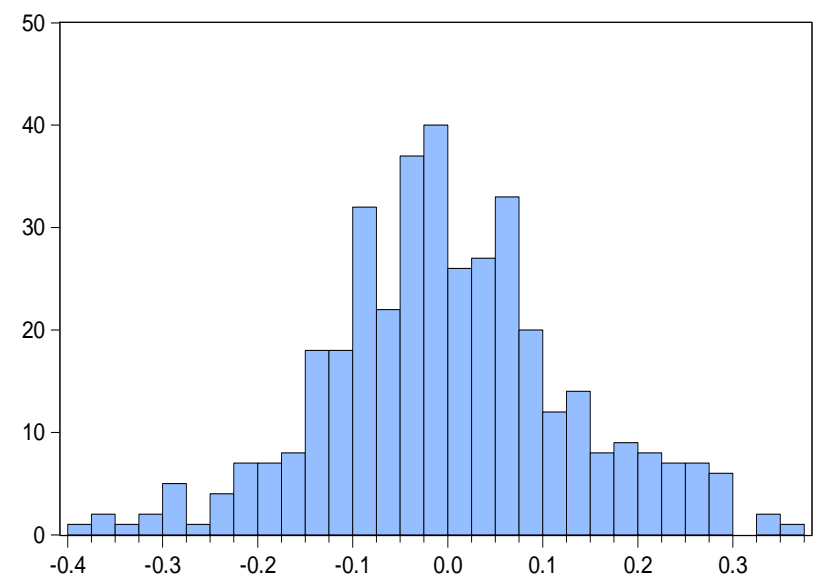

Series: Standardized Residuals Sample 20102014

Observations 385

Mean $\quad 1.73 \mathrm{e}-18$

Median $\quad-0.008158$

Maximum $\quad 0.371509$

Minimum $\quad-0.381335$

Std. Dev. $\quad 0.130463$

Skewness $\quad 0.048173$

Kurtosis $\quad 3.299828$

Jarque-Bera 1.591003

Probability $\quad 0.451355$

Figure (2): Jarque-Bera test of normality for residuals for SWFAG on R.

\section{5- Regression model:}

Stock Return $(\mathbf{R})=\mathbf{0 . 5 2 9 8 1 4}$ sales weighted sixed asset growth $-\mathbf{0 . 0 5 3 7 1 7}$ 
The Relation between Firm Growth and Stock Returns of ...

Ghada Saeed Abdelsalam Souliman

\section{6- Redundant fixed effect test:}

Table (8):

Redundant Fixed Effects Tests.

Test cross-section and period fixed effects

\begin{tabular}{cccc}
\hline \hline Effects Test & Statistic & d.f. & Prob. \\
\hline \hline Cross-section F & 8.157617 & $(76,303)$ & 0.0000 \\
Cross-section Chi-square & 428.841318 & 76 & 0.0000 \\
Period F & 0.499028 & $(4,303)$ & 0.7365 \\
Period Chi-square & 2.527995 & 4 & 0.6396 \\
Cross-Section/Period F & 7.773472 & $(80,303)$ & 0.0000 \\
Cross-Section/Period Chi- & 429.632593 & 80 & 0.0000 \\
square & & &
\end{tabular}

We notice that the first two tests ("Cross-section F" and "Cross-section Chi-square") evaluate the joint significance of the cross-section effects. The two statistic values are (8.16, 428.84). The associated p-values strongly reject the null that the cross-section effects are redundant, and there is crosssection fixed effect.

The next two tests evaluate the significance of the period dummies. The two statistic values $(0.499,2.528)$ and the associated p-values are greater than 0.01, so the forms of the statistic accept the null hypothesis of no period effects. 
The Relation between Firm Growth and Stock Returns of ...

Ghada Saeed Abdelsalam Souliman

The last two tests evaluate the joint significance of both effects. Both of the test statistics reject the null in which the cross-section and period are redundant. There is cross-section and period fixed effect.

\section{7- Cross-section fixed effects test equation:}

Table (9):

cross-section fixed effect test equation.

Variable Coefficient Std. Error t-Statistic Prob.

\begin{tabular}{lllll}
\hline \hline SWFAG & 0.180109 & 0.220707 & 0.816054 & 0.4150 \\
C & -0.055382 & 0.006768 & -8.183073 & 0.0000 \\
\hline \hline
\end{tabular}

Effects Specification

Period fixed (dummy variables)

Mean dependent

R-squared $\quad 0.003749$ var $\quad-0.056239$

Adjusted R-squared $\quad-0.009394 \quad$ S.D. dependent var 0.130574

Akaike info

S.E. of regression 0.131186 criterion $\quad-1.208947$

Sum squared resid $\quad 6.522453 \quad$ Schwarz criterion $\quad-1.147338$

Hannan-Quinn

Log likelihood 238.7223 criter. $\quad-1.184513$

F-statistic $\quad 0.285245 \quad$ Durbin-Watson stat 0.195980

Prob(F-statistic) $\quad 0.921096$ 
The Relation between Firm Growth and Stock Returns of ...

Ghada Saeed Abdelsalam Souliman

The panel model is as follows: $\mathrm{R}=0.180109 \mathrm{SWFAG}-0.055382$

Table (9) concludes that since the significant level of sales weighted fixed asset growth is greater than (0.05), so it is not accepted in the cross-section fixed effects test equation.

\section{8- Period fixed effects test equation:}

Table (10):

Period fixed effects test equation.

\begin{tabular}{ccccc}
\hline \hline Variable & Coefficient & Std. Error & t-Statistic & Prob. \\
\hline \hline SWFAG & 0.517586 & 0.237893 & 2.175709 & $0.01 \leq 7$ \\
C & -0.053776 & 0.004485 & -11.99095 & 0.0000 \\
\hline \hline \multicolumn{5}{c}{ Effects Specification } \\
\hline \hline
\end{tabular}

Cross-section fixed (dummy variables)

\begin{tabular}{cccc}
\hline \hline R-squared & 0.670791 & Mean dependent var & -0.056239 \\
Adjusted R-squared & 0.588221 & S.D. dependent var & 0.130574 \\
S.E. of regression & 0.083789 & Akaike info criterion & -1.942228 \\
Sum squared resid & 2.155329 & Schwarz criterion & -1.141311 \\
Log likelihood & 451.8789 & Hannan-Quinn criter. & -1.624581 \\
F-statistic & 8.123885 & Durbin-Watson stat & 0.598518 \\
Prob(F-statistic) & 0.000000 & & \\
\hline \hline
\end{tabular}

The panel model is as follows: $R=0.517586$ SWFAG -0.053776 
The Relation between Firm Growth and Stock Returns of ...

Ghada Saeed Abdelsalam Souliman

Table (10) concludes that since the significant level of sales weighted fixed asset growth is less than (0.05), so it is accepted in the period fixed effects test equation.

\section{9- Cross-section and period fixed effects test equation:}

Table (11):

Cross-section and period fixed effects test.

\begin{tabular}{ccccc}
\hline \hline Variable & Coefficient & Std. Error & t-Statistic & Prob. \\
\hline \hline SWFAG & 0.177402 & 0.219708 & 0.807443 & 0.4199 \\
C & -0.055395 & 0.006739 & -8.219668 & 0.0000 \\
\hline \hline R-squared & 0.001699 & Mean dependent var & 0.056239 \\
Adjusted R-squared & -0.000907 & S.D. dependent var & 0.130574 \\
S.E. of regression & 0.130633 & Akaike info criterion & - \\
& & & 1.227671 \\
Sum squared resid & 6.535872 & Schwarz criterion & - \\
& & & 1.207135 \\
Log likelihood & 238.3266 & Hannan-Quinn criter. & 1.219526 \\
F-statistic & 0.651965 & Durbin-Watson stat & 0.198935 \\
Prob(F-statistic) & 0.419912 & & \\
\hline \hline
\end{tabular}

The panel model is as follows: $\mathrm{R}=0.177402 \mathrm{SWFAG}-0.055395$ 
The Relation between Firm Growth and Stock Returns of ...

Ghada Saeed Abdelsalam Souliman

Table (11) concludes that since the significant level of sales weighted fixed asset growth is greater than (0.05), so it is not accepted in the cross-section and period fixed effects test equation.

\section{0- Residual Cross-Section Dependence Test}

Table (4.37):

Residual Cross-Section Dependence Test.

Null hypothesis: No cross-section dependence (correlation) in residuals

\begin{tabular}{cccc}
\hline \hline Test & Statistic & d.f. & Prob. \\
\hline \hline Breusch-Pagan LM & 9463.884 & 2926 & 0.0000 \\
Pesaran scaled LM & 84.45780 & & 0.0000 \\
Bias-corrected scaled LM & 74.83280 & & 0.0000 \\
Pesaran CD & -0.979868 & & 0.3272
\end{tabular}

Since the significant of Breusch-Pagan LM, Pesaran scaled LM, and Bias-corrected scaled LM are less than 0.001, then we reject the null hypothesis $\left(\mathrm{H}_{0}\right)$ : there is no crosssection dependence (correlation in residuals), But the significant of the last test (Pesaran CD) is greater than 0.05, so we accept the null: No cross-section dependence (correlation) in residuals. 
The Relation between Firm Growth and Stock Returns of ...

Ghada Saeed Abdelsalam Souliman

\section{5- CONCLUSION:}

The significant value of total asset growth does not impact on stock returns. Coefficient of determination $\left(\mathrm{R}^{2}\right)$ of total asset growth explains (66.94\%) of variation of stock returns and the rest $(33.06 \%)$ is due to either random error or other independent variables excluded from regression model. The significant value of F-test of total asset is less than 0.001, so the model can be accepted and results can be applied.

It has been concluded from the research that there is no effect of total asset growth on stock returns ie Egyptian Stock Exchange. It is inconsistent with previous studies such as Chen et al., (2008) applied on Pacific-Basin Region, Cooper et al., (2009) applied on U.S. market, Lipson et al., (2009) applied on U.S. market, and Wang et al., (2015) applied on China. So, $\mathrm{H}_{1}$ is rejected.

The significant value of sales weighted fixed asset growth has positive impact on stock returns. Coefficient of determination $\left(\mathrm{R}^{2}\right)$ of total asset growth explains $(67.29 \%)$ of variation of stock returns and the rest $(32.71 \%)$ is due to either randim error or other independent variables excluded from regression model. The significant value of F-test of sales weighted fixed asset growth is less than 0.001, so the model can be accepted and results can be applied.

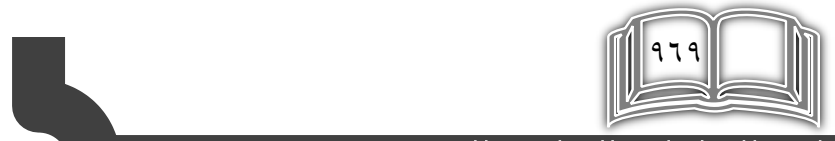


The Relation between Firm Growth and Stock Returns of ...

Ghada Saeed Abdelsalam Souliman

Second hypothesis which reveales that there a positive association between sales weighted fixed asset growth and stock returns in Egyptian Stock Exchange is accepted.

So, Research findings are: There is no association between total asset growth and stock returns, There is positive association between sales weighted fixed asset growth and stock returns.

\subsection{RECOMMENDATIONS}

According to the research findings, there are some recommendations to be presented: Through analyzing the impact of firm growth on stock returns. Firms can make future decisions related to firm growth. Since the sales weighted fixed asset growth impact postively on stock returns, the firm can rely on it to increase its stock returns. Since the total asset growth does not impact on stock returns, firm can take it on to account to increase stock returns.

The Research used data which are limited to the time period 2010 to 2014. Using data over a longer time period would have led to more accurate results of the study. Second, study sample excluded the firms with non-December 31 fiscal year-end, and firms trading in foreign currency. Third, the research has used only two measures of firm growth (TAG, and SWFAG); so, it is advisable for future research to use other measures of firm growth.

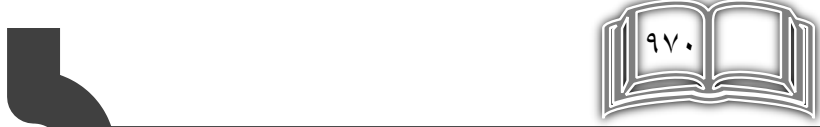


The Relation between Firm Growth and Stock Returns of ...

Ghada Saeed Abdelsalam Souliman

\section{REFERENCES}

Chen, S, Yao, T, Yu, T \& Zhang, T (April 2008), 'Asset Growth and Stock Returns: Evidence from the Pacific-Basin Markets', viewed 10 March 2016, https://www.cass.city.ac.uk/_data/assets/pdf_file/0011/76916/Yu-141REVISED.pdf.

Cooper, M,J, Gulen, H \& Schill, M, J ( August 2008), 'Asset Growth and The Cross-Section of Stock Returns', The Journal of Finance, Vol. LXIII, No. 4, pp. 1609-1651.

Cooper, M,J, Gulen, H \& Schill, M, J (2009), 'The Asset Growth Effect in Stock Returns', From http:// ssrn.com/abstract=1335524.

Eldomiaty, T, I (2010), 'The contribution of sales revenue management to firm growth: a test of two competing models', International journal of revenue management, Vol. 4, No. 2.

Gray, P \& Johnson, J (2011), 'The relationship between asset growth and the cross section of stock-returns', Journal of Banking \& Finance, Vol. 35, pp. 670-680.

Lipson, M, L, Mortal, S \& Schill, M, J (March 2009), 'What Explains the Asset Growth Effect in Stock Returns?' Viewed 10 March 2016, https://business.rice.edu/uploadedFiles/Faculty_and_Research/Academi c_Areas/Finance/Seminar_PDFs/Lipson.pdf.

Li, X, Becker, Y \& Rosenfeld, D (May/June 2012), 'Asset Growth and Future Stock Returns: International Evidence', Financial Analysis Journal, Vol. 68, No. 3, pp. 51-62. 
The Relation between Firm Growth and Stock Returns of ...

Ramakrishnan, S, Nabi, A, A \& Anuar, M, A (2014), 'Impact of Assets and Stock Returns of Listed Firms in the Food Industry of Pakistan Stock Market', Research Journal of Applied Sciences, Engineering and Technology, Vol. 8, No. 9, pp. 1170-1173.

Tahir, S, H, Sabir, H, M, Alam, T \& Ismail, A (2013), 'Impact of Firm's Characteristics on Stock Return: A Case of Non-Financial Listed Companies in Pakistan', Asian Economic and financial Review, Vol. 3, No. 1, pp. 51-61.

Yao, T, Yu, T, Zhang, T \&Chen, S (2011), 'Asset growth and stock returns: Evidence from Asian financial markets', Pacific-Basin Finance Journal, Vol. 19, pp. 115-139.

Wang, Y, Liu, C, Lee, J \& Wang, Y (2015), 'The relation between asset growth and the cross-section of stock returns: Evidence from the Chinese Stock Market', Economic Modelling, Vol. 44, pp. 59-67.

Watanabe, K, Xu, Y, Yao, T \& Yu, T (2013), 'The asset growth effect: Insights from international equity markets', Journal of Financial Economics, Vol. 108, pp. 529-563.

Wen, Q (2013), 'Asset Growth and Stock Market Returns: A Timeseries Analysis, http://finance.business.uconn.edu/wpcontent/uploads/sites/723/2014/08/ Asset-Growth-and-Stock-Market-Returns.pdf 